\title{
Corynebacterium timonense sp. nov. and Corynebacterium massiliense sp. nov., isolated from human blood and human articular hip fluid
}

Correspondence Véronique Roux vroux91@hotmail.com

\author{
Vicky Merhej, ${ }^{1}$ Enevold Falsen, ${ }^{2}$ Didier Raoult ${ }^{1}$ and Véronique Roux ${ }^{1}$ \\ ${ }^{1}$ Laboratoire de Bactériologie - Virologie, Hôpital de la Timone, URMITE CNRS-IRD UMR6236, \\ 264 rue Saint-Pierre, 13385 Marseille, Cedex 05, France \\ ${ }^{2}$ Culture Collection, University of Göteborg, Department of Clinical Bacteriology, Guldhedsg.10, S- \\ 41346 Göteborg, Sweden
}

The genus Corynebacterium is one of the largest genera in the coryneform group of bacteria, which consists of irregularly shaped, Gram-positive, strictly aerobic or facultatively anaerobic, asporogenous rods. Among this group, phenotypic identification at the species level on the basis of biochemical criteria remains problematic because of a lack of characteristic traits. The combination of chemotaxonomic markers (Collins et al., 1982; Von Graevenitz et al., 1994) and molecular approaches based on 16S rRNA and $r p o B$ gene sequence analyses has

The GenBank/EMBL/DDBJ accession numbers for the 16S rRNA gene sequence of strains $5401744^{\top}$ and $5402485^{\top}$ are EF217055 and EF217056, respectively; those for the $r p o B$ gene sequence of strains $5401744^{\top}$ and $5402485^{\top}$ are EF2 17058 and EF217057, respectively.

Electron micrographs of cells of strains $5401744^{\top}$ and $5402485^{\top}$ and neighbour-joining phylogenetic trees showing the position of strains $5401744^{\top}$ and $5402485^{\top}$ among representatives of the genus Corynebacterium inferred from $16 \mathrm{~S}$ rRNA and rpo $B$ gene sequence comparisons are available as supplementary material with the online version of this paper. improved the identification of members of the genus Corynebacterium (Khamis et al., 2004, 2005; Pascual et al., 1995; Roux et al., 2004; Ruimy et al., 1995; Tang et al., 2000). At the time of writing, the genus comprised 70 recognized species, most of which have been described since 2000. These Corynebacterium species have been isolated from human clinical sources (Feurer et al., 2004; Funke et al., 1995, 1997a, b, 1998; Riegel et al., 2006; Yassin, 2007), animal sources (Collins et al., 2001, 2004; Fernández-Garayzábal et al., 2004; Vela et al., 2003), and soil and vegetables (Chen et al., 2004; Fudou et al., 2002). In the present report, we describe two novel species of the genus Corynebacterium that were isolated from human blood and human articular hip fluid.

In May 2005, a 56-year-old man with a history of infective endocarditis underwent aortic and mitral valve replacement. Following surgery he developed bradycardia that required a pacemaker implant. Two months later, the patient was admitted to the emergency unit of the Timone 
Hospital. He presented with persistent fever, elevated erythrocyte sedimentation rate $\left(62 \mathrm{~mm} \mathrm{~h}^{-1}\right)$ and elevated C-reactive protein $\left(200 \mathrm{mg} \mathrm{l}^{-1}\right)$. His white blood cell count was $10500 \mathrm{ml}^{-1}$. Gram-positive coryneform bacteria (representative strain $5401744^{\mathrm{T}}$ ) were isolated from five of six blood cultures (three samples obtained on the first day of hospitalization and three others obtained on the second day). The patient was treated with vancomycin ( 2 g per day) and gentamicin (200 mg per day) intravenously and recovered.

In September 2005, an 84-year-old man who had previously undergone arthroplasty of his left hip presented with left knee pain and intermittent fever at Marseilles Hopital-Nord emergency unit. Synovial fluid was sampled and sent to the laboratory for bacterial culture. It contained many neutrophils without crystals. Gram-positive bacilli (representative strain $5402485^{\mathrm{T}}$ ) were isolated and identified as representing Corynebacterium sp. The patient was treated with antibiotics (amoxicillin, $3 \mathrm{~g}$ per day; rifampicin, $900 \mathrm{mg}$ per day) administered orally three times a day for 6 months.

In both cases no phenotypic identification of the bacteria was obtained. Genotypic identification based on 16S rRNA gene sequence comparisons suggested that strains $5401744^{\mathrm{T}}$ and $5402485^{\mathrm{T}}$ represent two novel species of the genus Corynebacterium.

Minimum inhibitory concentrations were determined according to the disc diffusion method, as there is, to our knowledge, no international guidelines for the antimicrobial susceptibility testing of coryneform bacteria. The two novel strains were susceptible to amoxicillin, doxycycline, rifampicin, vancomycin, trimethoprim-sulfamethoxazole, gentamicin, ofloxacin and clindamycin. Strain $5402485^{\mathrm{T}}$ was susceptible to erythromycin whereas strain $5401744^{\mathrm{T}}$ was resistant.

Surface colonies on sheep blood agar (bioMérieux) in 5\% $\mathrm{CO}_{2}$ were circular, $1-2 \mathrm{~mm}$ in diameter, smooth, shiny and yellow for strain $5401744^{\mathrm{T}}$ after $24 \mathrm{~h}$ incubation, and $0.5-$ $1 \mathrm{~mm}$ in diameter, circular, glistening and greyish for strain $5402485^{\mathrm{T}}$ after $48 \mathrm{~h}$ incubation. After $24 \mathrm{~h}$ incubation the colonies were not haemolytic. Growth was tested under anaerobic and microaerophilic atmospheres, which were created by using a GENbag anaer and GENbag microaer (bioMérieux), respectively, and in presence of air or $5 \% \mathrm{CO}_{2}$. Growth temperature was tested by incubation at $25,30,37,44$ and $50{ }^{\circ} \mathrm{C}$. The bacteria grew in aerobic and anaerobic atmospheres. Optimum growth was observed at $37{ }^{\circ} \mathrm{C}$ but occurred between 25 and $50{ }^{\circ} \mathrm{C}$ for strain $5401744^{\mathrm{T}}$ and between 30 and $44{ }^{\circ} \mathrm{C}$ for strain $5402485^{\mathrm{T}}$. The size and ultrastructure of cells were determined by using transmission electron microscopy. Cells were grown in liquid trypticase soy broth (TSB; Becton Dickinson) medium for $48 \mathrm{~h}$, collected by pipetting and stained with $1 \%(\mathrm{w} / \mathrm{v})$ phosphotungstic acid. Samples were examined on a Morgagni 268D (Philips) electron microscope at an operating voltage of $60 \mathrm{kV}$. Cells of strains $5401744^{\mathrm{T}}$ and $5402485^{\mathrm{T}}$ were Gram-positive, non- motile, non-spore-forming rods, $0.6-2.1 \mu \mathrm{m}$ long and $0.4-$ $0.6 \mu \mathrm{m}$ wide, and $0.2-1.8 \mu \mathrm{m}$ long and $0.3-0.7 \mu \mathrm{m}$ wide, respectively (see Supplementary Fig. S1 in IJSEM Online).

Catalase activity was determined by using the ID colour catalase test kit (bioMérieux). Oxidase activity was assayed by applying the cells to moistened discs that were impregnated with dimethyl-p-phenylene diamine (bioMérieux). Strains $5401744^{\mathrm{T}}$ and $5402485^{\mathrm{T}}$ were catalase-positive but oxidasenegative. The novel strains were characterized biochemically by using API Coryne and API ZYM strips (bioMérieux) according to the manufacturer's instructions. Phenotypic characteristics were compared with those of Corynebacterium auris CIP $104632^{\mathrm{T}}$, Corynebacterium lipophiloflavum CIP $105127^{\mathrm{T}}$, Corynebacterium mycetoides CIP $55.51^{\mathrm{T}}$, Corynebacterium capitovis CIP $106739^{\mathrm{T}}$, Corynebacterium casei CIP $107182^{\mathrm{T}}$, Corynebacterium ammoniagenes CIP $101283^{\mathrm{T}}$, Corynebacterium confusum CIP $105403^{\mathrm{T}}$, Corynebacterium macginleyi CIP $104099^{\mathrm{T}}$, Corynebacterium accolens CIP $104783^{\mathrm{T}}$, Corynebacterium tuberculostearicum CIP $107291^{\mathrm{T}}$ and Corynebacterium renale CIP $103421^{\mathrm{T}}$, which were the most closely related species based on 16S rRNA and $r p o B$ gene sequence comparisons (see below). Characteristic traits are presented in Table 1. Results of other tests for the novel strains are given in the species descriptions below.

Preparation and determination of cellular fatty acids were carried out according to the procedures given for the Sherlock Microbial Identification System (MIDI) except that the database and software package used to obtain a comparison of a new profile with one from the database were developed by the Culture Collection, University of Göteborg (CCUG). The cellular fatty acid profiles of strains $5401744^{\mathrm{T}}$ and $5402485^{\mathrm{T}}$ are detailed in Table 2.

Bacterial DNA was extracted by using the Magna Pure LC DNA isolation kit III (Roche) with a Magna Pure LC instrument, as described by the manufacturer. PCR amplification of the 16S rRNA and $r p o B$ genes was performed by using the universal primer pair $\mathrm{fD} 1$ and rp2 (Weisburg et al., 1991) and the primer pair cory2700f and cory3130r (Khamis et al., 2004), respectively. PCR products were purified by using MultiScreen PCR (Millipore) and sequencing reactions were carried out by using a DNA sequencing kit (BigDye Terminator Cycle Sequencing v1.1 Ready Reactions; PE Biosystems) according to the manufacturer's instructions. Sequencing products were purified and electrophoresis was performed with a 3100 Genetic Analyzer (Applied Biosystem). Gene sequences were aligned via the multisequence alignment program CLUSTAL_X (v. 1.8) (Thompson et al., 1997). Phylogenetic relationships with closely related species were determined by using MEGA version 4 (Tamura et al., 2007). Distance matrices were determined following the assumptions described by Kimura (1980) and were used to elaborate the dendrogram according to the neighbourjoining method (Saitou \& Nei, 1987). The maximumparsimony algorithm was also used to infer phylogenetic analysis. Bootstrap analysis (bootstrap values were 
Table 1. Differential phenotypic characteristics between strains $5401744^{\top}$ and $5402485^{\top}$ and related species of the genus Corynebacterium

Strains: 1, C. auris CIP $104632^{\mathrm{T}}$; 2, C. lipophiloflavum CIP $105127^{\mathrm{T}} ; 3$, C. mycetoides CIP $55.51^{\mathrm{T}} ; 4$, C. capitovis CIP $106739^{\mathrm{T}} ; 5$, $5401744^{\mathrm{T}}$ (C. timonense sp. nov.); 6, C. cystitidis CIP $103424^{\mathrm{T}} ; 7$, C. confusum CIP $105403^{\mathrm{T}} ; 8$, C. macginleyi CIP 104099 ${ }^{\mathrm{T}} ; 9$, C. accolens $\mathrm{CIP}_{104783^{\mathrm{T}}}$; 10, C. tuberculostearicum CIP $107291^{\mathrm{T}}$; 11, C. casei CIP $107182^{\mathrm{T}}$; 12, C. ammoniogenes CIP $101283^{\mathrm{T}}$; 13, 5402485 ${ }^{\mathrm{T}}$ (C. massiliense sp. nov.); 14 , C. renale CIP $103421^{\mathrm{T}}$; 15 , C. mastitidis CECT $4843^{\mathrm{T}}$. w, Weakly positive; +, positive; -, negative; v, variable.

\begin{tabular}{|c|c|c|c|c|c|c|c|c|c|c|c|c|c|c|c|}
\hline Characteristic & 1 & 2 & 3 & 4 & 5 & 6 & 7 & 8 & 9 & 10 & 11 & 12 & 13 & 14 & $15^{*}$ \\
\hline Aesculin hydrolysis & + & - & - & - & $\mathrm{w}$ & - & - & - & - & - & - & + & - & - & - \\
\hline Glucose & - & - & + & + & + & + & + & + & + & + & + & + & - & + & - \\
\hline Ribose & - & - & - & - & + & + & + & + & + & + & + & + & - & + & - \\
\hline Xylose & - & - & - & - & - & + & - & - & - & - & - & - & - & - & - \\
\hline \multicolumn{16}{|c|}{ Enzyme activities (API Coryne) } \\
\hline Pyrazinamidase & + & + & + & - & + & + & + & - & - & + & - & + & $\mathrm{w}$ & + & + \\
\hline Pyrrolidonyl arylamidase & - & - & $\mathrm{w}$ & - & - & - & - & - & + & - & + & - & - & - & - \\
\hline Urease & - & - & - & - & - & + & - & - & - & - & - & + & - & + & $\mathrm{V}$ \\
\hline \multicolumn{16}{|l|}{ Enzyme activities (API ZYM) } \\
\hline Leucine arylamidase & + & + & + & + & + & + & + & $\mathrm{W}$ & + & + & + & + & + & w & + \\
\hline Valine arylamidase & $\mathrm{w}$ & - & + & - & + & - & - & - & - & $\mathrm{w}$ & - & - & - & - & + \\
\hline Cystine arylamidase & + & - & + & - & - & + & $\mathrm{w}$ & - & - & $\mathrm{w}$ & + & - & - & - & + \\
\hline Trypsin & + & - & + & - & - & - & - & $\mathrm{w}$ & $\mathrm{w}$ & - & - & - & - & - & - \\
\hline Acid phosphatase & + & - & $\mathrm{w}$ & + & + & + & $\mathrm{w}$ & + & - & $\mathrm{w}$ & + & - & - & - & + \\
\hline
\end{tabular}

${ }^{\star}$ Results from Fernandez-Garayzabal et al. (1997).

obtained for a consensus tree based on 1000 randomly generated trees) was performed to investigate the stability of the trees obtained. Levels of $16 \mathrm{~S}$ rRNA gene sequence similarity were determined by using BioEdit software. Levels of similarity between strain $5401744^{\mathrm{T}}$ and the type strains of C. auris, C. capitovis, C. lipophiloflavum and C. mycetoides were 97.0, 96.6, 96.5 and $96.3 \%$, respectively; those between strain $5402485^{\mathrm{T}}$ and the type strains of $C$. macginleyi, C. accolens, C. tuberculostearicum, C. confusum, C. mastitidis and $C$. renale were 95.6, 95.3, 95.3, 94.5, 94.0 and $93.5 \%$, respectively. $16 \mathrm{~S}$ rRNA gene sequence similarity between strains $5401744^{\mathrm{T}}$ and $5402485^{\mathrm{T}}$ was $94.2 \%$. All the above values are $\leqslant 97 \%$, confirming that strains $5401744^{\mathrm{T}}$ and $5402485^{\mathrm{T}}$ represent two novel species of the genus Corynebacterium (Stackebrandt et al., 2002). Phylogenetic analysis inferred from 16S rRNA gene and $r p o B$ gene sequence comparisons according to the neighbour-joining and maximum-parsimony methods showed that strain $5401744^{\mathrm{T}}$ grouped with C. auris in a cluster also including C. capitovis, C. mycetoides and C. lipophiloflavum (Figs 1 and 2). Phylogenetic analysis inferred from $16 \mathrm{~S}$ rRNA gene sequence comparisons according to the neighbour-joining method showed that strain $5402485^{\mathrm{T}}$ grouped with $C$. confusum in a cluster also including $C$. tuberculostearicum, C. accolens and C. macginleyi (Fig. 1). In the maximum-parsimony tree, strain $5402485^{\mathrm{T}}$ grouped with $C$. renale and $C$. mastitidis in a cluster also including $C$. tuberculostearicum, C. accolens, C. macginleyi and $C$. confusum (data not shown). On the basis of $r p o B$ gene sequence comparisons, strain $5402485^{\mathrm{T}}$ formed a distinct subline within the genus Corynebacterium and clustered with C. casei and C. ammoniagenes (Fig. 2). None of the bootstrap values found were representative of stable nodes (all were $<95 \%$ ). The phylogenetic analyses based on $16 \mathrm{~S}$ rRNA and $r p o B$ gene sequence comparisons gave different clusterings for C. massiliense. Comparisons based on biochemical characteristics or fatty acid patterns (Table 1) did not allow us to determine the best phylogenetic approach.

Based on both phylogenetic and phenotypic evidence, strain $5401744^{\mathrm{T}}$ isolated from human blood culture and strain $5402485^{\mathrm{T}}$ isolated from articular hip fluid are considered to represent separate novel species of the genus Corynebacterium, for which the names Corynebacterium timonense sp. nov. and Corynebacterium massiliense sp. nov. are proposed, respectively.

Two other strains of C. massiliense sp. nov. (CCUG 49336 and CCUG 49589) and one other strain of C. timonense sp. 
Table 2. Whole-cell fatty acid compositions (\% of total) of strains $5401744^{\top}$ and $5402485^{\top}$ and and related species of the genus Corynebacterium

Strains: $1,5401744^{\mathrm{T}}$ (C. timonense sp. nov.); 2, C. auris CIP $104632^{\mathrm{T}} ; 3$, C. lipophiloflavum CIP $105127^{\mathrm{T}} ; 4$, C. mycetoides CIP $55.51^{\mathrm{T}}$; 5 , C. capitovis CIP $106739^{\mathrm{T}} ; 6,5402485^{\mathrm{T}}$ (C. massiliense sp. nov.); 7, C. cystitidis CIP $103424^{\mathrm{T}} ; 8$, C. confusum CIP $105403^{\mathrm{T}} ; 9$, C. macginleyi CIP $104099^{\mathrm{T}} ; 10$, C. accolens CIP $104783^{\mathrm{T}}$; 11, C. tuberculostearicum CIP $107291^{\mathrm{T}}$; 12, C. ammoniogenes CIP 101283 ${ }^{\mathrm{T}}$; 13, C. renale 103421 ${ }^{\mathrm{T}}$; 14 , C. mastitidis CIP $105509^{\mathrm{T}}$. - , Not detected.

\begin{tabular}{|c|c|c|c|c|c|c|c|c|c|c|c|c|c|c|}
\hline Fatty acid & $1^{\star}$ & $2^{*}$ & $3^{*}$ & $4^{*}$ & $5 \dagger$ & $6^{*}$ & $7^{\star}$ & $8^{\star}$ & $9^{*}$ & $10^{*}$ & $11^{\star}$ & $12^{\star}$ & $13^{\star}$ & $14^{\star}$ \\
\hline $\mathrm{C}_{14: 0}$ & - & 0.5 & - & - & - & 1.2 & - & - & 1.9 & - & - & 0.4 & - & 1.6 \\
\hline $\mathrm{C}_{15: 1} \omega 8 c$ & - & 2.3 & - & - & - & - & - & - & - & - & - & - & - & - \\
\hline $\mathrm{C}_{16: 1} \omega 11 c$ & 2.4 & - & - & - & - & - & - & - & - & - & - & - & - & - \\
\hline $\mathrm{C}_{16: 1} \omega 9 c$ & - & 0.8 & - & 3.2 & 3.0 & - & - & 1.8 & - & - & - & - & - & - \\
\hline $\mathrm{C}_{16: 1} \omega 7 c$ & - & - & - & - & - & 2.5 & - & - & 3.8 & - & - & - & - & 2.3 \\
\hline $\mathrm{C}_{16: 0}$ & 10.9 & 11.5 & 19.5 & 20.0 & 23.0 & 26.3 & 40.6 & 34.0 & 16.0 & 34.7 & 8.6 & 24.6 & 32.7 & 26.5 \\
\hline iso- $\mathrm{C}_{17: 1} \omega 5 c$ & - & 0.4 & - & - & - & - & - & - & - & - & - & - & - & - \\
\hline anteiso- $\mathrm{C}_{17: 0}$ & 3.3 & 3.2 & - & - & - & - & - & - & - & - & 3.8 & - & - & 0.4 \\
\hline $\mathrm{C}_{17: 1} \omega 9 c$ & 27.1 & - & - & - & - & - & - & - & - & - & 16.4 & 1.4 & 18.0 & - \\
\hline $\mathrm{C}_{17: 1} \omega 8 c$ & - & 27.8 & - & 5.5 & - & - & - & - & - & - & - & - & - & 0.5 \\
\hline $\mathrm{C}_{17: 0}$ & - & 13.3 & 15.6 & 8.3 & - & 1.6 & - & - & 3.0 & - & 0.8 & - & - & - \\
\hline $\mathrm{C}_{18: 2} \omega 6,9 c /$ anteiso- $\mathrm{C}_{18: 0}$ & 4.4 & 1.7 & 9.2 & - & - & 32.1 & 3.8 & 3.0 & 5.6 & 24.5 & 5.9 & 0.6 & 5.5 & 16.6 \\
\hline $\mathrm{C}_{18: 1} \omega 9 c$ & 36.4 & 22.1 & 39.4 & 56.1 & 67.8 & 22.5 & 50.8 & 56.3 & 49.5 & 27.7 & 58.7 & 39.7 & 40.2 & 28.1 \\
\hline $\mathrm{C}_{18: 0}$ & 6.1 & 5.2 & 16.5 & 6.8 & 6.1 & 11.0 & 4.9 & 4.9 & 7.3 & 13.2 & 3.7 & 3.9 & 3.8 & 13.5 \\
\hline 10-Methyl C $\mathrm{C}_{18: 0}$ (TSBA) & - & - & - & - & - & 2.7 & - & - & - & - & 1.3 & 2.3 & - & - \\
\hline $\mathrm{C}_{18: 0} 2-\mathrm{OH}$ & - & - & - & - & - & - & - & - & - & - & - & - & - & 1.4 \\
\hline $\mathrm{C}_{20: 4} \omega 6,9,12,15 c$ & - & - & - & - & - & - & - & - & - & - & - & - & - & 1.1 \\
\hline $\mathrm{C}_{18: 0} 3-\mathrm{OH}$ & - & - & - & - & - & - & - & - & - & - & - & - & - & 1.9 \\
\hline Unidentified & 9.4 & 11.4 & - & - & - & - & - & - & 12.7 & - & 0.8 & 27.3 & - & 5.8 \\
\hline
\end{tabular}

${ }^{\star}$ Result obtained from CCUG.

$\nmid$ Result obtained from Collins et al. (2001).

$¥$ TSBA, Tuberculostearic acid.

nov. (CCUG 47998) were deposited in the Culture Collection of the University of Göteborg. The biochemical characteristics and fatty acid profiles of strains CCUG 49336 and CCUG 49589 were similar to those of strain $5402485^{\mathrm{T}}$. $16 \mathrm{~S}$ rRNA (605 bp) and $r p o B$ (366 bp) gene sequence comparisons revealed $100 \%$ similarity for all three isolates of the species. The biochemical characteristics of strain CCUG 47998 were similar to those of strain $5401744^{\mathrm{T}}$. The fatty acid profiles of the two strains were different (Table 3) but $16 \mathrm{~S}$ rRNA (702 bp) and $r p o B$ (406 bp) gene sequence comparisons revealed $100 \%$ similarity.

\section{Description of Corynebacterium timonense sp. nov.}

Corynebacterium timonense (ti.mo.nen'se. N.L. neut. adj. timonense from the name Hôpital de la Timone, the name of the hospital in Marseille, France, where the type strain was isolated).

Cells are Gram-positive, non-spore-forming and nonmotile. They are typically club-shaped rods that occur as single cells, in pairs or in small clusters. The rods are 0.6$2.1 \mu \mathrm{m}$ in length and $0.4-0.6 \mu \mathrm{m}$ in diameter after $48 \mathrm{~h}$ growth in TSB medium (as determined by electron microscopy). After $24 \mathrm{~h}$ growth on sheep blood agar at $37{ }^{\circ} \mathrm{C}$, surface colonies are circular, yellow, shiny and 1$2 \mathrm{~mm}$ in diameter. Capable of aerobic and anaerobic growth. Temperature range for growth is $25-50{ }^{\circ} \mathrm{C}$ (optimum, $37^{\circ} \mathrm{C}$ ). Catalase-positive. With the API Coryne system, acid is produced from D-glucose and D-ribose, but not from D-xylose, D-mannitol, maltose, D-lactose, sucrose or glycogen. Nitrate is not reduced. Aesculin is weakly hydrolysed but urea and gelatin are not hydrolysed. With API Coryne and API ZYM strips, positive for pyrazinamidase, alkaline phosphatase, esterase (C4), esterase lipase (C8), lipase (C14) (weakly), leucine arylamidase, valine arylamidase and acid phosphatase, but negative for pyrrolidonyl arylamidase, cystine arylamidase, trypsin, $\alpha$ chymotrypsin, naphthol-AS-BI-phosphohydrolase, $\alpha$-galactosidase, $\beta$-galactosidase, $\beta$-glucuronidase, $\alpha$-glucosidase, $\beta$ glucosidase, $N$-acetyl- $\beta$-glucosaminidase, $\alpha$-mannosidase and $\alpha$-fucosidase. The fatty acid profile is characterized by the predominance of $\mathrm{C}_{18: 1} \omega 9 c, \mathrm{C}_{17: 1} \omega 9 c, \mathrm{C}_{16: 0}$ and $\mathrm{C}_{18: 0}$. Tuberculostearic acid is not detected.

The type strain, $5401744^{\mathrm{T}} \quad\left(=\mathrm{CSUR} \quad \mathrm{P} 20^{\mathrm{T}}=\mathrm{CIP}\right.$ $109424^{\mathrm{T}}=$ CCUG $53856^{\mathrm{T}}$ ), was isolated from human blood. CCUG 47998 is a second strain of the species. 


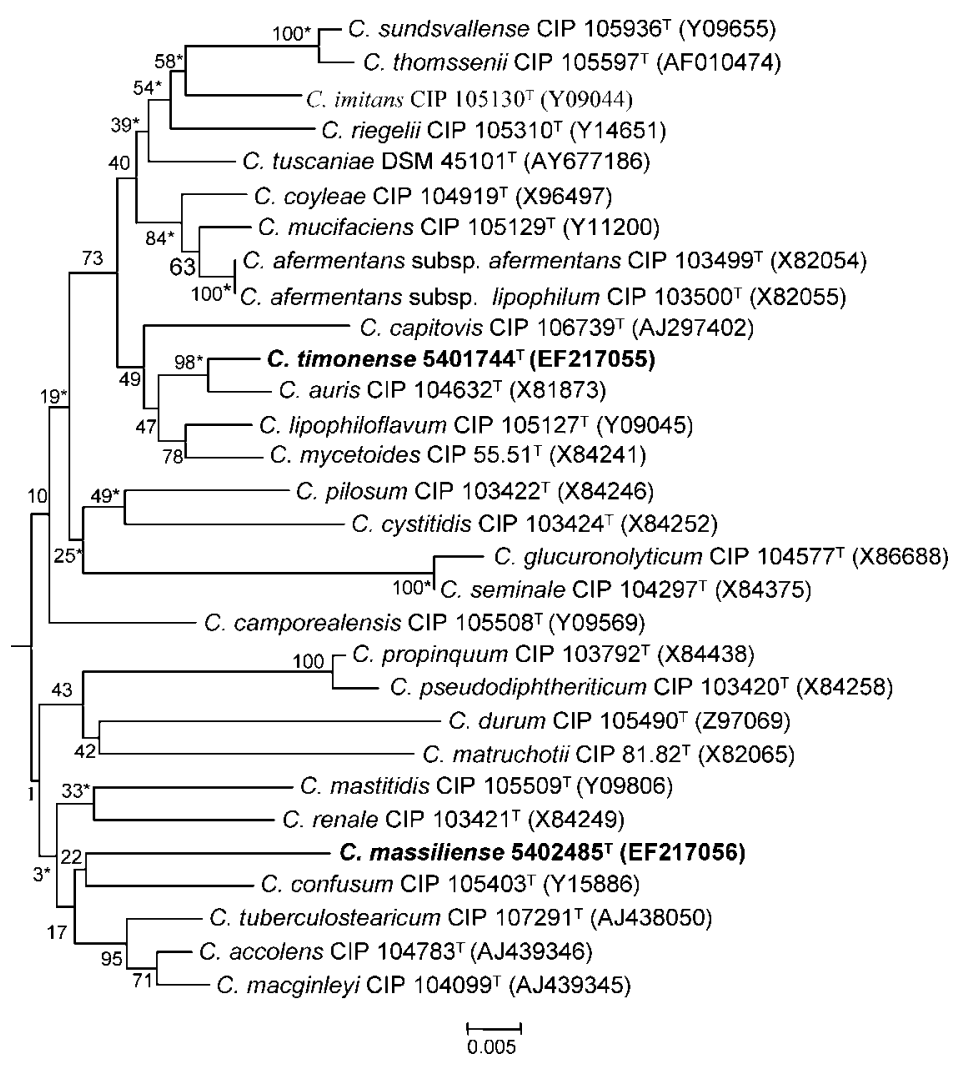

Fig. 1. Phylogenetic tree showing the positions of strains $5401744^{\top}$ and $5402485^{\top}$ among representatives of the genus Corynebacterium inferred from 16S rRNA gene sequence comparisons (1274 nt fragment) according to the neighbour-joining method. Numbers at nodes are bootstrap percentages based on 1000 resamplings. The sequence of the type strain of Mycobacterium smegmatis was used as the outgroup (AB305022; not shown). Bar, 0.005 changes per nucleotide position. An extended tree containing a wider selection of reference sequences is available in Supplementary Fig. S2 in IJSEM Online. Asterisks indicate nodes that were conserved when using the maximumparsimony method.

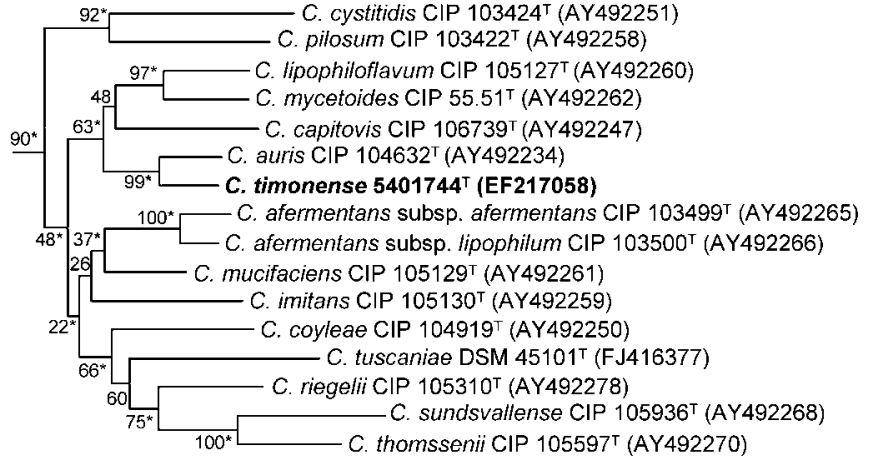

$\overrightarrow{0.02}$

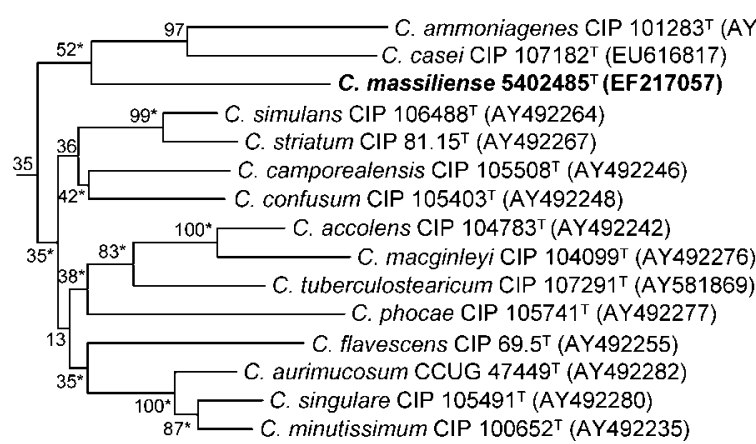

Fig. 2. Phylogenetic trees showing the positions of strains $5401744^{\top}$ and $5402485^{\top}$ among representatives of the genus Corynebacterium inferred from rpoB gene sequence comparisons (406 nt fragment) according to the neighbour-joining method. Numbers at nodes are bootstrap percentages based on 1000 resamplings that support the topology shown. The sequence of the type strain of Mycobacterium smegmatis was used as the outgroup (CP000480; not shown). Bar, 0.02 changes per nucleotide position. An extended tree containing a wider selection of reference sequences is available in Supplementary Fig. S3 in IJSEM Online. Asterisks indicate nodes that were conserved when using the maximum-parsimony method. 
Table 3. Whole-cell fatty acid compositions (\% of the total) of strains $5401744^{\top}$ and CCUG 47998

- , Not detected.

\begin{tabular}{|lcc|}
\hline Fatty acid & $\mathbf{5 4 0 1 7 4 4}^{\text {T }}$ & CCUG $\mathbf{4 7 9 9 8}$ \\
\hline $\mathrm{C}_{14: 0}$ & - & 0.7 \\
Unknown & 4.0 & - \\
$\mathrm{C}_{15: 0}$ & - & 8.0 \\
$\mathrm{C}_{16: 1} \omega 11 c$ & 2.4 & 0.5 \\
$\mathrm{C}_{16: 0}$ & 10.9 & 21.4 \\
anteiso-C $17: 0$ & 3.3 & 2.8 \\
$\mathrm{C}_{17: 1} \omega 9 c$ & 27.1 & 4.1 \\
$\mathrm{Unknown}$ & 5.4 & - \\
$\mathrm{C}_{17: 0}$ & - & 4.0 \\
$\mathrm{C}_{18: 2} \omega 6,9 c /$ anteiso- $\mathrm{C}_{18: 0}$ & 4.4 & 10.3 \\
$\mathrm{C}_{18: 1} \omega 9 c$ & 36.4 & 36.2 \\
$\mathrm{C}_{18: 0}$ & 6.1 & 12.1 \\
\hline
\end{tabular}

\section{Description of Corynebacterium massiliense sp. nov.}

Corynebacterium massiliense (mas.si.li.en'se. L. neut. adj. massiliense of Massilia, the old Roman name for Marseille, from where the type strain was isolated).

Cells are Gram-positive, non-spore-forming and nonmotile. They are typically club-shaped rods that occur as single cells, in pairs or in small clusters. The rods are $0.2-$ $1.8 \mu \mathrm{m}$ in length and $0.3-0.7 \mu \mathrm{m}$ in diameter after $48 \mathrm{~h}$ growth in TSB medium (as determined by electron microscopy). After $48 \mathrm{~h}$ growth on sheep blood agar, surface colonies are circular, greyish, glistening and 0.5$1 \mathrm{~mm}$ in diameter. Capable of aerobic growth but only weak anaerobic and microaerophilic growth. Temperature range for growth is $30-44{ }^{\circ} \mathrm{C}$ (optimum, $37{ }^{\circ} \mathrm{C}$ ). Catalasepositive. With the API Coryne system, acid is not produced from D-glucose, D-ribose, D-xylose, D-mannitol, maltose, D-lactose, sucrose or glycogen. Nitrate is not reduced. Urea, gelatin and aesculin are not hydrolysed. With API Coryne and API ZYM strips, positive for leucine arylamidase, weakly positive for pyrazinamidase, alkaline phosphatase, esterase (C4) and esterase lipase (C8), but negative for pyrrolidonyl arylamidase, lipase (C14), valine arylamidase, cystine arylamidase, trypsin, $\alpha$-chymotrypsin, acid phosphatase, naphthol-AS-BI-phosphohydrolase, $\alpha$-galactosidase, $\beta$-galactosidase, $\beta$-glucuronidase, $\alpha$-glucosidase, $\beta$ glucosidase, $N$-acetyl- $\beta$-glucosaminidase, $\alpha$-mannosidase and $\alpha$-fucosidase. The fatty acid profile is characterized by the predominance of a mixture of $\mathrm{C}_{18: 2} \omega 6,9 c$ and anteiso- $\mathrm{C}_{18: 0}, \mathrm{C}_{16: 0}, \mathrm{C}_{18: 1} \omega 9 c$ and $\mathrm{C}_{18: 0}$. Tuberculostearic acid is detected for strains $5402485^{\mathrm{T}}$ and CCUG 49589).

The type strain, $5402485^{\mathrm{T}} \quad\left(=\mathrm{CSUR} \quad \mathrm{P} 19^{\mathrm{T}}=\mathrm{CIP}\right.$ $109423^{\mathrm{T}}=$ CCUG $53857^{\mathrm{T}}$ ), was isolated from human hip joint fluid. CCUG 49336 and CCUG 49589 are additional strains of the species.

\section{Acknowledgements}

We are grateful to Bernard Campagna and Nicolas Aldrovendi for their technical assistance with electron microscopy and to Kent Molin (University of Göteborg, Sweden) for his technical assistance in cellular fatty acid analysis.

\section{References}

Chen, H.-H., Li, W.-J., Tang, S.-K., Kroppenstedt, R. M., Stackebrandt, E., Xu, L.-H. \& Jiang, C.-L. (2004). Corynebacterium halotolerans sp. nov., isolated from saline soil in the west of China. Int J Syst Evol Microbiol 54, 779-782.

Collins, M. D., Goodfellow, M. \& Minnikin, D. E. (1982). A survey of the structures of mycolic acids in Corynebacterium and related taxa. J Gen Microbiol 128, 129-149.

Collins, M. D., Hoyles, L., Foster, G., Sjoden, B. \& Falsen, E. (2001). Corynebacterium capitovis sp. nov., from a sheep. Int J Syst Evol Microbiol 51, 857-860.

Collins, M. D., Hoyles, L., Foster, G. \& Falsen, E. (2004). Corynebacterium caspium sp. nov., from a Caspian seal (Phoca caspica). Int J Syst Evol Microbiol 54, 925-928.

Fernandez-Garayzabal, J. F., Collins, M. D., Hutson, R. A., Fernandez, E., Monasterio, R., Marco, J. \& Dominguez, L. (1997). Corynebacterium mastitidis sp. nov., isolated from milk of sheep with subclinical mastitis. Int J Syst Bacteriol 47, 1082-1085.

Fernández-Garayzábal, J. F., Vela, A. I., Egido, R., Hutson, R. A., Lanzarot, M. P., Fernández-García, M. \& Collins, M. D. (2004). Corynebacterium ciconiae sp. nov., isolated from the trachea of black storks (Ciconia nigra). Int J Syst Evol Microbiol 54, 2191-2195.

Feurer, C., Clermont, D., Bimet, F., Candrea, A., Jackson, M., Glaser, P., Bizet, C. \& Dauga, C. (2004). Taxonomic characterization of nine strains isolated from clinical and environmental specimens, and proposal of Corynebacterium tuberculostearicum sp. nov. Int J Syst Evol Microbiol 54, 1055-1061.

Fudou, R., Jojima, Y., Seto, A., Yamada, K., Kimura, E., Nakamatsu, T., Hiraishi, A. \& Yamanaka, S. (2002). Corynebacterium efficiens sp. nov., a glutamic-acid-producing species from soil and vegetables. Int J Syst Evol Microbiol 52, 1127-1131.

Funke, G., Lawson, P. A. \& Collins, M. D. (1995). Heterogeneity within human-derived centers for disease control and prevention (CDC) coryneform group ANF-1-like bacteria and description of Corynebacterium auris sp. nov. Int J Syst Bacteriol 45, 735-739.

Funke, G., Hutson, R. A., Hilleringmann, M., Heizmann, W. R. \& Collins, M. D. (1997a). Corynebacterium lipophiloflavum sp. nov. isolated from a patient with bacterial vaginosis. FEMS Microbiol Lett 150, 219-224.

Funke, G., Lawson, P. A. \& Collins, M. D. (1997b). Corynebacterium mucifaciens sp. nov., an unusual species from human clinical material. Int J Syst Bacteriol 47, 952-957.

Funke, G., Osorio, C. R., Frei, R., Riegel, P. \& Collins, M. D. (1998). Corynebacterium confusum sp. nov., isolated from human clinical specimens. Int J Syst Bacteriol 48, 1291-1296.

Khamis, A., Raoult, D. \& La Scola, B. (2004). $r p o B$ gene sequencing for identification of Corynebacterium species. J Clin Microbiol 42, 3925-3931.

Khamis, A., Raoult, D. \& La Scola, B. (2005). Comparison between $r p o B$ and $16 \mathrm{~S}$ rRNA gene sequencing for molecular identification of 168 clinical isolates of Corynebacterium. J Clin Microbiol 43, 19341936. 
Kimura, M. (1980). A simple method for estimating evolutionary rates of base substitutions through comparative studies of nucleotide sequences. J Mol Evol 16, 111-120.

Pascual, C., Lawson, P. A., Farrow, J. A., Gimenez, M. N. \& Collins, M. D. (1995). Phylogenetic analysis of the genus Corynebacterium based on $16 S$ rRNA gene sequences. Int J Syst Bacteriol 45, 724-728.

Riegel, P., Creti, R., Mattei, R., Nieri, A. \& von Hunolstein, C. (2006). Isolation of Corynebacterium tuscaniae sp. nov. from blood cultures of a patient with endocarditis. J Clin Microbiol 44, 307-312.

Roux, V., Drancourt, M., Stein, A., Riegel, P., Raoult, D. \& La Scola, B. (2004). Corynebacterium species isolated from bone and joint infections identified by $16 \mathrm{~S}$ rRNA gene sequence analysis. J Clin Microbiol 42, 2231-2233.

Ruimy, R., Riegel, P., Boiron, P., Monteil, H. \& Christen, R. (1995). Phylogeny of the genus Corynebacterium deduced from analyses of small-subunit ribosomal DNA sequences. Int J Syst Bacteriol 45, 740746.

Saitou, N. \& Nei, M. (1987). The neighbor-joining method: a new method for reconstructing phylogenetic trees. Mol Biol Evol 4, 406-425.

Stackebrandt, E., Frederiksen, W., Garrity, G. M., Grimont, P. A. D., Kämpfer, P., Maiden, M. C. J., Nesme, X., Rossello-Mora, R., Swings, J. \& other authors (2002). Report of the ad hoc committee for the re-evaluation of the species definition in bacteriology. Int $J$ Syst Evol Microbiol 52, 1043-1047.
Tamura, K., Dudley, J., Nei, M. \& Kumar, S. (2007). MEGA4: molecular evolutionary genetics analysis (MEGA) software version 4.0. Mol Biol Evol 24, 1596-1599.

Tang, Y. W., Von Graevenitz, A., Waddington, M. G., Hopkins, M. K., Smith, D. H., Li, H., Kolbert, C. P., Montgomery, S. O. \& Persing, D. H. (2000). Identification of coryneform bacterial isolates by ribosomal DNA sequence analysis. J Clin Microbiol 38, 1676-1678.

Thompson, J. D., Gibson, T. J., Plewniak, F., Jeanmougin, F. \& Higgins, D. G. (1997). The CLUSTAL_X windows interface: flexible strategies for multiple sequence alignment aided by quality analysis tools. Nucleic Acids Res 25, 4876-4882.

Vela, A. I., Mateos, A., Collins, M. D., Briones, V., Hutson, R. A., Dominguez, L. \& Fernandez-Garayzabal, J. F. (2003). Corynebacterium suicordis sp. nov., from pigs. Int J Syst Evol Microbiol 53, 2027-2031.

Von Graevenitz, A., Pünter, V., Gruner, E., Pfyffer, G. E. \& Funke, G. (1994). Identification of coryneform and other gram-positive rods with several methods. APMIS 102, 381-389.

Weisburg, W. G., Barns, S. M., Pelletier, D. A. \& Lane, D. J. (1991). 16 S ribosomal DNA amplification for phylogenetic study. J Bacteriol 173, 697-703.

Yassin, A. F. (2007). Corynebacterium ureicelerivorans sp. nov., a lipophilic bacterium isolated from blood culture. Int J Syst Evol Microbiol 57, 1200-1203. 